\title{
VIVA MEDIKA
}

Jurnal Kesehatan, Kelidanan, dan TKeperawatan

http://ejournal.uhb.ac.id/index.php/VM/issue/archive

\section{PEMBERIAN KOMBINASI EKSTRAK ETANOL DAUN PEPAYA (Carica papaya L.) PADA MENCIT}

\author{
Rani Prabandari ${ }^{1}$ \\ ${ }^{1}$ Program Studi Sarjana Farmasi, Fakultas Kesehatan Universitas Harapan Bangsa \\ raniprabandari@uhb.ac.id
}

\begin{abstract}
ABSTRAK
Obat alami telah dikenal dan digunakan di seluruh dunia. Salah satunya adalah pepaya. Khasiat daun pepaya memberikan khasiat seperti demam, penambah nafsu makan, menstruasi yang diberi laun dan mengurangi rasa sakit. Penelitian ini bertujuan untuk mengetahui apakah pengaruh ekstrak etanol daun pepaya terhadap daya analgesik asam mefenamat pada mencit dengan menggunakan metode induksi asam asetik.

Penelitian ini adalah penelitian eksperimental menggunakan dua puluh empat tikus. Hewan-hewan ini dibagi menjadi enam kelompok di mana masing-masing kelompok terdiri dari empat tikus. Daun pepaya, asam mefenamat, dan aquadest diberikan kepada masing-masing kelompok sebagai zat uji dan larutan pembanding. Pengamatan dilakukan selama 10 menit menggunakan metode induksi asam asetik adalah penurunan mekanisme perlindungan tikus dalam menjilati atau respon kaki kaku setelah pemberian zat uji.

Terjadi penurunan respons tikus terhadap jilatan kaki atau kaki kaku terhadap induksi asam asetik yang diberikan setelah pemberian ekstrak daun pepaya. Ekstrak daun pepaya memiliki efek analgesik pada tikus.
\end{abstract}

Kata kunci: Analgesik, ekstrak daun pepaya, asam asetik.

\begin{abstract}
The natural medicine has been known and used through out of the world. One of them is papaya. Efficacy papaya leave provide efficacy as fever, appetite enhancer, launsed menstruation and relieve pain. This study aims to determine whether the effect of aethanol extract of papaya leaf against power analgesic mefenamic acid on mice by using the method asetic acid induction.

This study is an experimental study using twenty four mice. This animals were divided into six groups where each group consisting of four mice. Papaya leaves, mefenamic acid, and aquadest were give to each group as test substances and comparative solution. Observations were carried out for 10 minute using the method of asetic acid induction was a decreases of protection mechanism of the mice in of licking or stiff feet responses after the administration of test substances.

There was a decrease of the response of mice to lick feet or stiff feet to the asetic acid induction were given after administration of papaya leaf extract. The extract of papaya leaves has an analgesic effect on mice.
\end{abstract}

Keyword : Analgesic, papaya leaf extract, asetic acid.

Viwa Medika | VOLUME 11/NOMOR 02/MARET/2019 
Viva Medika: Jurnal Kesehatan, Kebidanan, dan Keperawatan, 11 (02), Maret 2019

Rani Prabandari (Pemberian Kombinasi Ekstrak Etanol Daun Pepaya (carica papaya l.) Pada Mencit)

\section{PENDAHULUAN}

Tanaman obat sudah dikenal dan digunakan di seluruh dunia. Salah satu jenis tanaman obat yang sering digunakan yaitu papaya (Carica papaya L.). Daun pepaya memberikan khasiat sebagai penurun demam, penambah nafsu makan, melancarkan haid dan pereda nyeri (analgesik) (Dalimatra S, 2009). Carica papaya $L$ dikenal sebagai papaya yang merupakan tanaman daerah tropis. Tanaman ini berasal dari meksiko bagian selatan dan nikaragua, papaya masuk ke Indonesia pada abad ke-17 dibawa oleh pedagang Gujarat dan india. Bagian batang, daun, dan buah papaya muda kecuali akar dan biji papaya memiliki getah yang mengandung enzim pemecah protein (proteolitik) yang disebut papain. Enzim papain juga banyak dipakai sebagai pengobatan karena enzim papain memiliki efek antiinflamasi (Kalie, 1999). (Lassarus dkk, 2013) peneliti sebelumnya Lassarus dkk, meneliti tentang uji analgesik tramadol terhadap ekstrak daun papaya pada mencit, daun papaya memiliki daya analgetik. Daun pepaya yang sudah di ekstrak lalu dilakukan pengujian terhadap Viua Medika | VOLUME 11/NOMOR 02/MARET/2019 hewan uji yaitu mencit, untuk mendapatkan hasil jika dibandingkan dengan tramadol efek analgetiknya sedikit lebih baik dibandingkan tramadol.

Metode maserasi digunakan untuk mendapatkan ekstrak daun papaya.

\section{METODE PENELITIAN}

Penelitian ini menggunakan metode eksperimental yang menggunakan hewan uji yaitu mencit sebanyak 24 ekor. Hewan dibagi dalam 6 kelompok dimana setiap kelompok terdiri dari 4 ekor mencit, yaitu kelompok blangko, kelompok kontrol negatif, kelompok kontrol positif dan kelompok eksperimen yang diberikan ekstrak daun papaya.

Alat

Alat-alat yang digunakan dalam melakukan penelitian yaitu timbangan analitik, seperangkat alat maserasi, alat-alat gelas Pyrek Iwaki Glass, spuit injeksi (0,1$1 \mathrm{ml}$ ) dan sonde, stopwatch sport timer, blender, cawan petri, oven, dan tabung reaksi. 
Viva Medika: Jurnal Kesehatan, Kebidanan, dan Keperawatan, 11 (02), Maret 2019

Rani Prabandari (Pemberian Kombinasi Ekstrak Etanol Daun Pepaya (carica papaya l.) Pada Mencit)

Bahan

Bahan yang digunakan pada saat penelitian yaitu daun papaya, alkohol $70 \%$, aquadest, obat analgesik (asam mefenamat sirup).

\section{Cara Kerja}

\section{Cara pembuatan ekstrak daun pepaya}

Sebanyak 100 gram serbuk kering daun pepaya yang telah dihaluskan dimaserasi dengan alkohol $70 \%$ sebanyak $150 \mathrm{~mL}$ selama \pm 7 hari terlindung dari sinar cahaya. Selama proses perendaman setiap hari dilakukan pengadukan selama 15 menit. Hasil penyarian kemudian disaring menggunakan kain flannel. Kemudian filtrat yang diperoleh dikumpulkan dan dipekatkan dengan waterbath sampai didapatkan ekstrak pekat. Ekstrak inilah yang digunakan dalam penelitian.

\section{Penyiapan larutan ekstrak}

Ekstrak daun papaya sebanyak 1 gram dimasukkan kedalam tabung reaksi diencerkan dengan $10 \mathrm{ml}$ aquadest. Diaduk hingga homogen. Dibuat konsentrasi $0,5 \mathrm{mg} / \mathrm{ml}, 1 \mathrm{mg} / \mathrm{ml}, 2 \mathrm{mg} / \mathrm{ml}$ untuk diberikan ke kelompok perlakuan hewan uji.

Pengujian efek analgesic

Viwa Medika | VOLUME 11/NOMOR 02/MARET/2019
24 ekor mencit jantan dibagi 6 kelompok perlakuan, dibiarkan selama satu minggu untuk beradaptasi dengan lingkungan, diberi makan dan minum secukupnya. Perlakuan tiap kelompok, kelompok pertama diberikan makan dan minum saja, kelompok kedua diberikan diinduksikan asam asetat (kontrol negatif), kelompok ketiga diberikan asam mefenamat dan induksi asam asetat (kontrol positif), kelompok keempat diberikan ekstrak papaya $0,5 \mathrm{mg}$ dan asam mefenamat $1,3 \mathrm{mg}$, kelompok kelima diberikan ekstrak pepaya $1 \mathrm{mg}$ dan asam mefenamat $1,3 \mathrm{mg}$, kelompok keenam diberikan ekstrak papaya $2 \mathrm{mg}$ dan asam mefenamat $1,3 \mathrm{mg}$. Setiap kelompok diinduksikan dengan 0,2gr/20gr asam asetat $1 \%$ untuk menghasilkan rasa sakit. Lakukan pengamatan respon dari mencit yaitu dengan melihat berapa kali mencit menggeliat dengan mengangkat kakinya. Pada menit 05, 5-10, 10-30, 30-60, 60-90, 90-120 sampai geliat menghilang, setelah pemberian zat uji.

\section{Penyajian Analisis Data}

Data hasil pengamatan dikumpulkan dan disajikan dalam bentuk tabel dan grafik. 
Viva Medika: Jurnal Kesehatan, Kebidanan, dan Keperawatan, 11 (02), Maret 2019

Rani Prabandari (Pemberian Kombinasi Ekstrak Etanol Daun Pepaya (carica papaya l.) Pada Mencit)

\section{HASIL PENELITIAN}

Data hasil penelitian awal yaitu uji determinasi. Uji Determinasi ini dilakukan di Laboratorium Taksonomi Tumbuhan Fakultas Biologi Universitas Jendral Soedirman Purwokerto dengan sampel daun pepaya (Carica papaya L.). Uji determinasi dilakukan untuk mengetahui kebenaran identitas daun pepaya yang digunakan dalam penelitian ini. Dalam uji determinasi ini, diperoleh hasil bahwa sampel yang digunakan untuk penelitian adalah spesies Carica Papaya L., yang termasuk famila

\section{Caricaceae.}

Sampel daun pepaya dikeringkan dengan cara dijemur dibawah sinar matahari langsung dengan ditutup kain hitam untuk menghindari hilangnya zat-zat yang ada dalam daun pepaya, kemudian setelah daun kering untuk memperkecil ukuran dihaluskan dengan menggunakan blender agar memudahkan tertariknya komponenkomponen kimia yang terdapat dalam daun pepaya pada proses maserasi (voight, 1995).

Proses ekstraksi dilakukan dengan metode maserasi menggunakan etanol $70 \%$ sebagai cairan penyari, dalam penelitian ini digunakan modifikasi remaserasi yaitu Viwa Medika | VOLUME 11/NOMOR 02/MARET/2019 seluruh simplisia dimaserasi dengan cairan penyari pertama, sesekali diaduk kemudian diendapkan, tuangkan dan diperas, ampas dimaserasi lagi dengan cairan maserasi kedua dan ketiga. Metode ekstraksi maserasi digunakan karena merupakan cara ekstraksi yang menggunakan alat dan cara yang mudah dan sederhana. Selain itu, maserasi juga merupakan metode ekstraksi cara dingin yang cocok digunakan untuk simplisia yang zat aktifnya tidak tahan terhadap pemanasan (Anonim, 1999).

Dalam penelitian ini telah dilakukan uji efek analgesik dengan menggunakan ekstrak daun pepaya sebagai kelompok perlakuan. Obat asam mefenamat sebagai kontrol positif dan asam asetat sebagai kontrol negatif. Sebelum diberikan zat uji, terlebih dahulu diamati jumlah respon hewan uji terhadap rangsang nyeri (menjilat dan atau melompat), supaya dapat dilihat perbandingan antara sebelum dan sesudah pemberian zat uji. Penelitian ini dilakukan untuk mengetahui ada tidaknya efek analgetik dari ekstrak daun pepaya dengan menggunakan metode induksi asam asetat yang diuji pada mencit. Rangsangan yang diberikan pada hewan uji yaitu berupa 
Viva Medika: Jurnal Kesehatan, Kebidanan, dan Keperawatan, 11 (02), Maret 2019

Rani Prabandari (Pemberian Kombinasi Ekstrak Etanol Daun Pepaya (carica papaya l.) Pada Mencit)

rangsangan menjilat atau geliat pada salah satu kaki mencit. Pada penelitian ini respon mencit yang dinilai berupa gerakan menjilat kaki dan atau melompat. Sebagai tolak ukur, bahwa mencit mulai merasakan nyeri pada waktu menjilat kaki belakang dan atau melompat, karena menjilat kaki depan adalah hal normal bagi mencit (Turner dalam Lassarus, Johanis A. Najoan, Jane Wuisan. 2012).

Tabel 1. Jumlah Rata-Rata Geliat Hewan uji selama 90 menit pada perlakuan

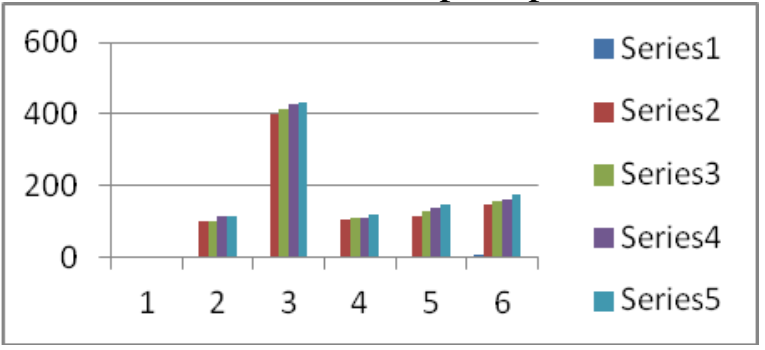

Keterangan :

1. Hewan diberi makan dan minum saja

2. Hewan diinduksikan larutan Asam Asetat 1 $\%$ per injeksi (kontrol negatif)

3. Hewan diberikan Asam Mefenamat sirup, kemudian diinduksikan asam asetat $1 \%$ per injeksi (kontrol positif)

4. Hewan diberikan Asam Mefenamat sirup $(0,13 \mathrm{ml})$ dalam ekstrak papaya $(0,5 \mathrm{mg})$ [perlakuan I]

Viwa Medika | VOLUME 11/NOMOR 02/MARET/2019
5. Hewan diinduksikan Larutan Asam Mefenamat $(0,13 \mathrm{ml})$ dalam ekstrak papaya (1 mg) [perlakuan II]

6. Hewan diinduksikan Larutan Asam Mefenamat $(0,13 \mathrm{ml})$ dalam ekstrak papaya (2mg) [perlakuan III]

Tabel 2. Jumlah Geliat Mencit dalam waktu 90 menit

\begin{tabular}{c|c|c|c|c|c|c}
\hline \multirow{2}{*}{$\begin{array}{c}\text { Kelompok } \\
\text { Perlakuan }\end{array}$} & \multicolumn{7}{|c}{ Jumlah geliat mencit } \\
\cline { 2 - 7 } & $0 "-5 "$ & $\begin{array}{c}5 "- \\
10^{\prime \prime}\end{array}$ & $\begin{array}{c}10^{\prime \prime}- \\
20^{\prime \prime}\end{array}$ & $\begin{array}{c}20 "- \\
30^{\prime \prime}\end{array}$ & $\begin{array}{c}30^{\prime \prime}- \\
60^{\prime \prime}\end{array}$ & $\begin{array}{c}60^{\prime \prime}- \\
90^{\prime \prime}\end{array}$ \\
\hline 1 & 0 & 0 & 0 & 0 & 0 & 0 \\
\hline 2 & 13 & 17 & 45 & 27 & 23 & 8 \\
\hline 3 & 85 & 75 & 69 & 65 & 57 & 60 \\
\hline 4 & 30 & 33 & 35 & 10 & 3 & 0 \\
\hline 5 & 45 & 33 & 32 & 17 & 5 & 0 \\
\hline 6 & 56 & 33 & 22 & 22 & 7 & 0 \\
\hline
\end{tabular}

Tabel 3. Geliat Mencit dalam waktu 90 menit

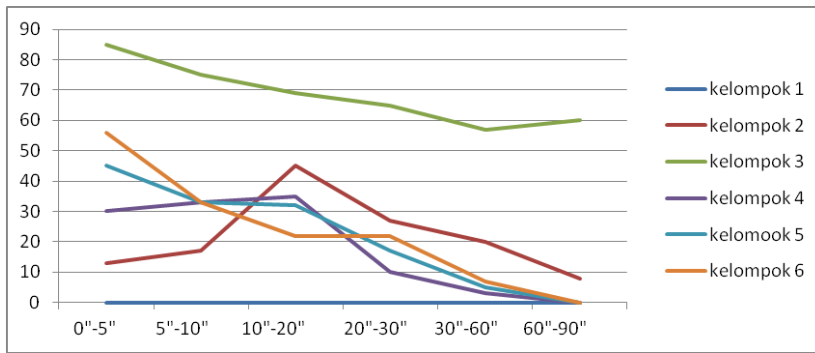

Pada kelompok kontrol positif yang diberikan asam mefenamat, tidak menunjukkan terjadi penurunan respon ratarata hewan uji terhadap rangsangan nyeri. Efek analgetik dari kelompok kontrol positif tetap terlihat sampai akhir pengujian pada menit ke-90. Efek analgetik asam 
Viva Medika: Jurnal Kesehatan, Kebidanan, dan Keperawatan, 11 (02), Maret 2019

Rani Prabandari (Pemberian Kombinasi Ekstrak Etanol Daun Pepaya (carica papaya l.) Pada Mencit)

mefenamat pada penelitian ini mencapai puncaknya pada menit ke-90. Pada manusia, efek analgetik asam mefenamat mencapai puncak pada waktu 2-4 jam. Berdasarkan penelitian pada kontrol positif, efek analgesik asam mefenamat pada mencit timbul pada menit ke-30 setelah pemberian oral dan puncaknya pada menit ke-90. Hal ini disebabkan karena faktor perbedaan spesies antara manusia dengan mencit yakni perbedaan metabolisme mencit dan manusia, namun untuk efek analgetik asam mefenamat sesuai dengan teori yang mengatakan bahwa efek analgesik asam mefenamat mencapai puncak dalam waktu 2-4 jam (Gunawan,2008).

Ekstrak etanol pepaya (dosis 0,5 $\mathrm{ml} / \mathrm{kgBB}$ ) terlihat efek analgetiknya pada menit ke-20 setelah perlakuan dan tetap memperlihatkan efek analgetiknya sampai menit ke-90. Efek analgetik ekstrak etanol (dosis $1 \mathrm{ml} / \mathrm{kgBB}$ ) mencapai puncaknya pada menit ke-30.Pada menit ke-90, efek analgetiknya sudah hilang hal ini terlihat dari rata-rata respon nyeri mencit pada menit ke-90 lebih tinggi dari rata-rata respon nyeri mencit sebelum perlakuan.
Data yang didapatkan dari kelompok perlakuan (ekstrak etanol daun pepaya) terlihat bahwa efek yang ditimbulkan oleh ekstrak papaya (dosis $0,5 \mathrm{ml} / \mathrm{kgBB}$ ) dan asam mefenamat $0,13 \mathrm{ml}$ hampir sama. Hal ini berarti potensi analgetik ekstrak papaya sama dengan asam mefenamat $0,13 \mathrm{ml}$ dalam mengurangi rasa nyeri pada mencit yang diinduksi asam asetat. Ekstrak papaya (dosis $1 \mathrm{ml} / \mathrm{kgBB}$ ) dan (dosis $2 \mathrm{ml} / \mathrm{kgBB}$ ) mempunyai efek analgetik yang lebih baik dari asam mefenamat terutama dosis ekstrak papaya $2 \mathrm{ml}$ yang merupakan dosis maksimum pada penelitian ini. Hal ini disebabkan oleh perbedaan dosis yang diberikan dimana dosis $1 \mathrm{ml}$ dan $2 \mathrm{ml}$ lebih besar daripada dosis asam mefenamat. Pemberian dosis yang lebih tinggi dari ekstrak etanol daun pepaya ini dimaksudkan untuk mendapatkan efek analgetik yang lebih pasti. Hasil pengujian pada kelompok perlakuan yang diberi dosis berbeda, menunjukkan adanya efek analgetik ekstrak etanol daun pepaya pada hewan uji. Hal ini terlihat dari penurunan rata-rata respon nyeri dari mencit sebelum perlakuan dibandingkan setelah perlakuan. 
Viva Medika: Jurnal Kesehatan, Kebidanan, dan Keperawatan, 11 (02), Maret 2019

Rani Prabandari (Pemberian Kombinasi Ekstrak Etanol Daun Pepaya (carica papaya l.) Pada Mencit)

Ketiga kelompok perlakuan memiliki efek analgetik hanya sampai pada menit ke60. Pada menit ke-90 sudah tidak memiliki efek analgetik. Penurunan efek ekstrak etanol daun pepaya disebabkan karena waktu paruh ekstrak yang cepat dan berbeda dengan waktu paruh senyawa sintetik yang lebih lama. Tanpa melihat perbedaan dosis ekstrak etanol daun pepaya yang diberikan penelitian ini membuktikan bahwa secara farmakologis tumbuhan ini memiliki efek analgetik. Ekstrak etanol daun papaya memiliki efek analgetik karena kandungan flavonoid. Flavonoid berperan sebagai analgetik yang mekanisme kerjanya menghambat kerja enzim siklogenase (Suryanto, 2012). Dengan demikian akan mengurangi produksi prostaglandin oleh asam arakidonat sehingga mengurangi rasanyeri (Gunawan, 2008). Dari hasil pengamatan yang dilakukan pada mencit yang diinduksi menggunakan asam asetat, terlihat bahwa tidak semuamencit menunjukkan respon yang sama. Ketidaksamaan tersebut antara lain, adayang memberikan respon lompatan atau hanya berupa jilatan atau keduanya danjumlah respon mencit yang berbeda-beda sebelum Vwa Medika | VOLUME 11/NOMOR 02/MARET/2019 perlakuan. Hal ini disebabkan oleh faktor yang mempengaruhi metabolisme obat atau ekstrak yang diberikan pada mencit, antara lain yaitu genetik atau keturunan, perbedaan umur, makanan dan penyakit (Coleman, 2010). Melihat banyaknya faktor yang dapat mempengaruhi, dapat disimpulkan bahwa adanya spesifitas individual terhadap induksi nyeri yang diberikan dan respon mencit terhadap pemberian obat dan ekstrak pun berbeda-beda, sehingga hasil data pengamatan berbeda-beda setiap mencit walaupun dalam kelompok perlakuan yang sama, namun pada keseluruhan rata-rata hasil pengamatan ini menunjukkan respon sesuai dengan yang diharapkan dari masingmasing kelompok.

Berdasarkan dari hasil pemberian ekstrak etanol daun papaya, enzim papain yang digunakan memberikan sifat asam dan asam mefenamat mempengaruhi enzim tersebut terlihat pada grafik kelompok perlakuan, ekstrak etanol daun papaya memberikan efek positif, dengan menaikan daya analgetik asam mefenamat. Dan hasil grafik diperkuat dengan hasil sistem komputer SPSS, menunjukkan ada pengaruh 
Viva Medika: Jurnal Kesehatan, Kebidanan, dan Keperawatan, 11 (02), Maret 2019

Rani Prabandari (Pemberian Kombinasi Ekstrak Etanol Daun Pepaya (carica papaya l.) Pada Mencit)

penaikan efek ekstrak etanol daun papaya pada mencit.

Hasil analisis menggunakan SPSS (Statistical Package for the Social Science), uji yang dipakai dalam analisis data ini adalah uji normalitas (saphiro-wilk) dan uji kruskall wallis. Pada uji saphiro-wilk table sigma menunjukkan angka 0 , hal tersebut menunjukan sig $<\propto=0,05$ dapat disimpulkan data tidak terdistribusi normal

\section{Analisis Data}

\section{Uji Normalitas Data (Saphiro-Wilk)}

Pengujian normalitas data dilakukan untuk melihat data dapat terdistribusi normal atau tidak. Jika terdistribusi normal dapat menggunakan one way annova, jika tidak terdistribusi normal dapat menggunakan uji kruskallwallis.

\section{Hasil Uji Normalitas}

Tests of Normality

\begin{tabular}{|l|c|c|c|c|c|c|}
\hline \multirow{2}{*}{} & \multicolumn{2}{|c|}{$\begin{array}{c}\text { Kolmogorov- } \\
\text { Smirnov }\end{array}$} & \multicolumn{4}{|c|}{ Shapiro-Wilk } \\
\cline { 2 - 7 } & $\begin{array}{c}\text { Statist } \\
\text { ic }\end{array}$ & df & Sig & $\begin{array}{c}\text { Statisti } \\
\text { c }\end{array}$ & df & Sig. \\
\hline $\begin{array}{l}\text { jmlh_g } \\
\text { eliat_m } \\
\text { encit }\end{array}$ &, 334 & 24 &, 00 &, 676 & 24 &, 000 \\
\hline
\end{tabular}

a. Lilliefors Significance Correction

Viwa Medika | VOLUME 11/NOMOR 02/MARET/2019
Tabel uji normalitas menunjukkan bahwa nilai Sig pada kolom saphiro-wilk adalah 0. Hal tersebut menunjukkan bahwa Sig $<\alpha=$ 0,05, maka dapat disimpulkan bahwa data berdistribusi tidak normal.

\section{Histogram}

Histogram tersebut menunjukkan bahwa kurva yang terbentuk tidak normal sehingga menunjukkan data tidak berdistribusi normal. Dilanjutkan dengan uji krusskal wallis, dikarenakan data yang dihasilkan tidak normal

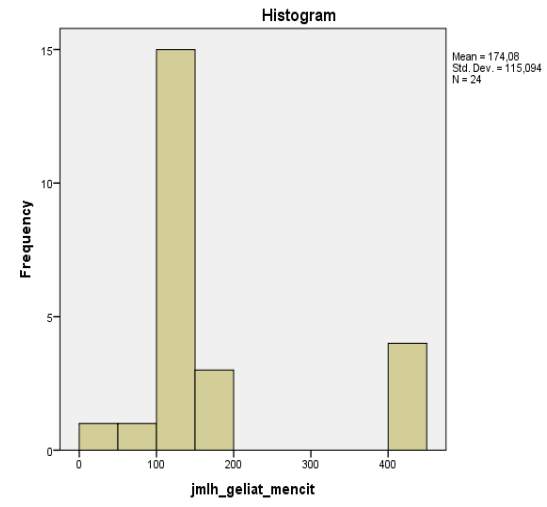

\section{Hasil Analisis Kruskal Wallis}

Ranks

\begin{tabular}{|r|l|r|r|}
\hline & $\begin{array}{l}\text { perlakua } \\
\mathrm{n}\end{array}$ & $\mathrm{N}$ & \multicolumn{1}{|c|}{ Mean Rank } \\
\hline & 1 & 4 & 2,50 \\
& 2 & 4 & 8,50 \\
rataratage & 3 & 4 & 22,50 \\
liatmencit & 4 & 4 & 9,25 \\
& 5 & 4 & 13,88 \\
& 6 & 4 & 18,38 \\
& Total & 24 & \\
\hline
\end{tabular}


Viva Medika: Jurnal Kesehatan, Kebidanan, dan Keperawatan, 11 (02), Maret 2019

Rani Prabandari (Pemberian Kombinasi Ekstrak Etanol Daun Pepaya (carica papaya l.) Pada Mencit)

Terlihat bahwa untuk masing-masing perlakuan terdapat empat kali replikasi pengukuran. Rata-rata ranking terbesar adalah perlakuan 3 dan rata-rata ranking terkecil yaitu perlakuan 1 .

Test Statistics ${ }^{\mathrm{a}, \mathrm{b}}$

\begin{tabular}{|l|r|}
\hline & $\begin{array}{c}\text { rataratageliat } \\
\text { mencit }\end{array}$ \\
\hline Chi- & 21,139 \\
Square & 5 \\
df &, 001 \\
Asymp. & \\
Sig. & \\
\hline
\end{tabular}

a. Kruskal Wallis Test

b. Grouping Variable: perlakuan

Pada tabel tersebut diketahui bahwa nilai asymp Sig adalah 0,001 . Nilai tersebut jika dibandingkan dengan $\alpha=5 \%$, maka lebih kecil sehingga H0 ditolak. Kesimpulannya adalah "Ada perbedaan ratarata geliat mencit yang dihasilkan antar kelompok perlakuan".

\section{Uji Mean Whitney}

\section{Ranks}

\begin{tabular}{|l|l|c|c|c|}
\hline & $\begin{array}{l}\text { perl } \\
\text { akua } \\
\text { n }\end{array}$ & $\begin{array}{c}\text { N } \\
\text { Rank }\end{array}$ & $\begin{array}{c}\text { Mea } \\
\text { Ranks }\end{array}$ & $\begin{array}{c}\text { Sum } \\
\text { of }\end{array}$ \\
\hline $\begin{array}{l}\text { rataratag } \\
\text { eliatmen } \\
\text { cit }\end{array}$ & $\begin{array}{l}5 \\
6\end{array}$ & 2,63 & 10,50 \\
& $\begin{array}{l}\text { Tota } \\
1\end{array}$ & 8,38 & 25,50 \\
& & \\
\hline
\end{tabular}

Tabel diatas menunjukkan bahwa rata peringkat kelompok perlakuan 5 yaitu 2,63 lebih rendah dari pada rerata peringkat kelompok perlakuan 6 yaitu 6,38.

Test Statistics $^{\mathrm{a}}$

\begin{tabular}{|l|r|}
\hline & $\begin{array}{r}\text { rataratageliat } \\
\text { mencit }\end{array}$ \\
\hline Mann-Whitney U &, 500 \\
Wilcoxon W & 10,500 \\
$Z$ & $-2,178$ \\
Asymp. Sig. (2-tailed) &, 029 \\
Exact Sig. [2*(1-tailed &, $029^{\mathrm{b}}$ \\
Sig.)] & \\
\hline
\end{tabular}

a. Grouping Variable: perlakuan

b. Not corrected for ties.

Hasil uji diatas menunjukkan bahwa terdapat beberapa perlakuan yang menghasilkan hasil yang berbeda dan cukup signifikan. Jika dianalisa diketahui bahwa kelompok perlakuan 6 memiliki perbedaan yang signifikan dengan seluruh kelompok perlakuan yang lain. Selain itu, kelompok perlakuan 6 juga menghasilkan rata-rata jumlah geliat mencit paling banyak. Hal tersebut menunjukkan bahwa kelompok perlakuan 3 paling efektif dalam hal menaikkan daya analgetik asam mefenamat pada mencit dilihat dari kumulatif geliat mencit yang dihasilkan dibandingkan dengan kelompok perlakuan yang lain. 
Viva Medika: Jurnal Kesehatan, Kebidanan, dan Keperawatan, 11 (02), Maret 2019

Rani Prabandari (Pemberian Kombinasi Ekstrak Etanol Daun Pepaya (carica papaya l.) Pada Mencit)

\section{SIMPULAN DAN SARAN}

Berdasarkan data penelitian yang telah dilaksanakan maka diperoleh kesimpulan, enzim papain yang digunakan memberikan sifat asam dan asam mefenamat mempengaruhi enzim tersebut terlihat pada grafik kelompok perlakuan, ekstrak etanol daun papaya memberikan efek positif, dengan menaikan daya analgetik asam mefenamat. Dan hasil grafik diperkuat dengan hasil SPSS, menunjukkan ada pengaruh penaikan efek ekstrak etanol daun papaya pada mencit dan ditandai adanya geliat pada mencit setelah perlakuan, dilanjutkan uji mean whitney didapatkan hasil ekstrak papaya yang paling efektif adalah $2 \mathrm{ml}$.

Saran peneliti selanjutnya dapat melanjutkan penelitian ekstrak daun papaya dengan menggunakan dosis yang berbeda dan metode yang berbeda pula

\section{DAFTAR PUSTAKA}

Anonim,1999. Pharmakope. Indonesia. Depkes RI. Jakarta.

Brunton L, Parker K, Blumenthal D, Buxton I, Goodman \& Gilman's Manual of Pharmacology and Therapeutics.2008. McGraw-Hill

Viwa Medika | VOLUME 11/NOMOR 02/MARET/2019
Coleman M, D. 2010. Factor affecting drug metabolism. UK: Wiley-Blackwell

Dalimatra S. Atlas Tumbuhan Obat Indonesia Jilid 6. Jakarta; pustaka Bunda;2009.

Direktorat Gizi, Departemen KesehatanRI. 1992. Daftar Komposisi BahanMakanan. Bharata Jakarta.

Dirjen POM Departemen Kesehatan Republik Indonesia. (1995).Farmakope

Dollery, Colin. 1991. Therapeutic drug. Churchill Livingstone. A 143.

Fitri Dwiyana, Ummul, Supardan, Ummi Kaltsum. 2009. Efek analgesik antara dekok dan ekstrak kasar daun pepaya (Carica papaya L.) pada tikus (RattusNovergicus) Strain Wistar yang diEvaluasidengan Writhing Test. Fakultas Universitas Muhammadiyah Magelang.

Gunawan, S.G., Setiabudy, R., Nafrialdi,Elsyabeth, editor. 2008.Farmakologi dan Terapi Edisi 5.FKUI, Jakarta.

Hasti, S., Sandi, N.H., san Srianti, T., 2011. Uji Efek Analgetika Ekstrak Etanol, Fraksi Etil Asetat dan Fraksi Heksan Akar Gantung Beringin (Ficus benjamina L.) Pada Mencit Putih Jantan (Mus Musculus). 
Viva Medika: Jurnal Kesehatan, Kebidanan, dan Keperawatan, 11 (02), Maret 2019

Rani Prabandari (Pemberian Kombinasi Ekstrak Etanol Daun Pepaya (carica papaya l.) Pada Mencit)

Hastono Sutanto dan Sabri Luknis. 2010. Statistik kesehatan.Jakarta: RajawaliPers

Indonesia. Edisi IV. Jakarta: Departemen Kesehatan Republik Indonesia.Hal. $1083,1084$.

ISFI., (2009). Informasi Spesialite Obat Indonesia. Volume 44.Jakarta : Penerbit PT. ISFI Penerbitan. Halaman $303-311$.

Januarsih Iwan A.R, Nur Atik. 2010. Perbandingan Pemberian Topikal Aqueous Leaf Extract of Carica Papaya (ALEC) dan Madu Khaula Terhadap Percepatan Penyembuhan Luka Sayat Pada Kulit Mencit (Musmusculus). Bagian Histologi Fakultas Kedokteran Universitas Padjajaran, Bandung.

Kalie, M. 1999. Bertanam Pepaya.Jakarta: Penebar Swadaya.

Lassarus, Johanis A. Najoan, Jane Wuisan. 2012. Uji efek analgesik ekstrak daun pepaya (Carica papaya L.) Pada mencit (Mus Musculus). Farmakologi dan Farmakoterapi Fakultas Kedokteran Universitas Sam Ratulangi Manado.

Malole, M.B.M. and Pramono,C.S.U. 1989.Pengantar Hewan-Hewan Percobaan di Laboratorium. Bogor. Pusat Antara Universitas Bioteknologi IPB.
Mutschler, E. 1991.Dinamika Obat. Penerjemah: Matilda, B.W. Bandung: ITB. Hal : 608-615

Sugiyono. 2010. Statistika untuk Penelitian. Bandung: Alfabeta, ISBN.

Tjay, T.H., dan Rahardja, K. (1999). Obatobat Penting. EdisiIV. CetakanKedua. Jakarta: Penerbit PT Elex Media Komputindo. Hal. 135,142

Turner. 1965. Didalam Puspitasari, H.2003. Aktivitas Analgetik EkstrakUmbi Teki (Cyperus rotundus L.)pada Mencit Putih (Mus musculusL.) Jantan. Biofarmasi 1 (2): 50-57.

Voigt, R. 1994. Buku Pelajaran Teknologi Farmasi edisi 5.EGC. Jakarta

Warisno, 2003. Budidaya Pepaya. Yogyakarta: Kanisius. hal. 9-10, 15-16

Winarno, F.G. 1986. Pangan: Gizi, Teknologi dan Konsumen. Jakarta: Gramedia Pustaka Utama. 